\title{
Peran mikrobiota usus dalam perkembangan obesitas
}

\author{
Susmiati \\ Fakultas Keperawatan, Universitas Andalas
}

Korespondensi: Susmiati,email: susmiati@nrs.unand.ac.id

\begin{abstract}
Abstrak
Sampai sekarang etiologi obesitas masih belum jelas dan masih diperdebatkan. Baru-baru ini mikrobiota usus dianggap sebagai salah satu faktor yang berperan terhadap kejadian obesitas. Tujuan: Untuk membahas tentang peran mikrobiota usus terhadap kejadian obesitas. Metode: Artikel ini disusun berdasarkan review beberapa literature yang berhubungan dengan peran mikrobiota usus baik pada hewan coba maupun pada manusia dengan berbagai metode penelitian. Hasil: Pada penelusuran literature didapatkan peran mikrobiota usus terhadap kejadian obesitas dapat melalui beberapa mekanisme yaitu melalui jalur metabolik, inflamasi dan hormonal. Jalur metabolik dengan peningkatan produksi Short-Chain Fatty Acid (SCFA), perubahan metabolisme asam empedu dan FXR/TGR5 signaling, jalur inflamasi dengan peningkatan lipopolisakarida (LPS) dan endocannabinoid (eCB) system yang mengatur metabolisme dan rasa lapar melalui microbiota-gut-brain axis serta jalur hormonal yaitu penekanan fiaf, peningkatan Peptide YY (PYY), dan ekspresi dari G protein coupled receptors (GPCRs). Simpulan: Beberapa penelitian menunjukkan mekanisme utama peran mikrobiota terhadap perkembangan obesitas dapat melalui jalur metabolik, inflamasi, maupun hormonal.
\end{abstract}

Kata kunci: mikrobiota usus; jalur metabolik; inflamasi; hormonal; obesitas

\begin{abstract}
Until nowadays, the etiology of obesity is still unclear and debatable. Recently, gut microbiota is thought as a factor that play a role in obesity prevalence. Objectives: This article aims to discuss on the role of gut microbiota on obesity occurrence. Methods: This article is compiled on some literature related to the role of gut microbiota in animals as well as in human specimens, with various research methods. Results: Literature study reveals that the role of gut microbiota on obesity prevalence may be mediated by metabolic, inflammation, and hormonal pathways. The metabolic way consists of increasing Short-Chain Fatty Acid (SCFA) production, bile acid, and FXR/TGR5 signaling. The inflammation way comprises lipopolysaccharide (LPS) increment and endocannabinoid (eCB) system that regulates metabolism and hunger through microbiota-gut-brain axis. The hormonal mechanisms are by fiaf suppression, Peptide YY (PYY) increase, and expression of $G$ protein coupled receptors (GPCRs). Conclusions: Some studies show the main mechanism of the role of microbiota on the development of obesity can be through metabolic, inflammatory, and hormonal pathways. Keywords: gut microbiota; metabolic; inflammation; hormonal pathway; obesity
\end{abstract}




\section{PENDAHULUAN}

Saat ini obesitas tidak hanya menjadi masalah di negara maju, tetapi juga menjadi masalah dinegara berkembang. Walaupun berbagai cara tatalaksana dan pencegahan dilakukan melalui pengaturan pola makan dan aktivitas fisik, namun angka kejadian obesitas terus meningkat. Sampai sekarang penyebab pasti obesitas masih belum jelas dan masih diperdebatkan.

Obesitas pada anak dan remaja dianggap sebagai faktor risiko utama untuk obesitas di masa dewasa, yang menyebabkan periode ini menjadi lebih penting. Efek kesehatan jangka panjang obesitas dapat berkembang menjadi gangguan metabolisme glukosa, hipertensi, sindrom metabolik dan penyakit kardiovaskuler, berbagai penyakit kanker serta masalah tulang dan sendi, sleep apnea ${ }^{1}$ dan masalah-masalah sosial dan psikologis seperti stigmatisasi dan harga diri rendah, stres, dan psychiatric disorders ${ }^{2}$ dan gangguan kualitas hidup. ${ }^{3}$

Penyebab obesitas masih diperdebatkan, karena tidak semua orang menjadi gemuk ketika tinggal di lingkungan yang sama. Tidak semua orang yang mengonsumsi lebih banyak energi dan bertambah berat badannya. Beberapa individu bisa menaikkan atau menekan berat badan lebih mudah daripada yang lain. Risiko obesitas tergantung pada beberapa faktor yang saling berinteraksi, yaitu varian genetik (polimorfisme nukleotida tunggal) dan risiko paparan lingkungan (diet tinggi lemak, kurangnya aktivitas fisik) dan kebiasaan hidup. Faktor genetik dan lingkungan serta interaksi antara keduanya berkontribusi terhadap obesitas. Variabilitas antar individu diduga dihasilkan dari heritabilitas gen yang berisiko obesitas yang berinteraksi dengan komponen lain dalam lingkungan obesogenic yang kemudian mendukung terhadap keseimbangan positif untuk peningkatan berat badan. ${ }^{4}$

Mikrobiota usus baru-baru ini telah dikemukakan sebagai faktor lingkungan yang bertanggung jawab untuk kenaikan berat badan dan gangguan metabolisme energi yang menyebabkan penyakit kardiometabolik lain seperti aterosklerosis, obesitas dan diabetes melitus type 2 . Mikrobiota usus mengubah metabolisme dengan meningkatkan ekstraksi energi, modulasi sistem imunologi, dan mempengaruhi metabolisme lipid. ${ }^{5}$ Penelitian terbaru lebih difokuskan pada modifikasi mikrobiota usus sebagai strategi dalam pengobatan penyakit kardiovaskuler dan gangguan metabolik.

\section{METODE}

Penulisan artikel ini berdasarkan studi kepustakaan yang berhubungan dengan peran mikrobiota usus terhadap perkembangan obesitas dan gangguan metabolik lainnya.

\section{HASIL DAN PEMBAHASAN}

Faktor yang mempengaruhi komposisi mikrobiota usus 
Perubahan komposisi mikroba usus manusia dikemukakan menjadi penyebab lain kejadian obesitas. Komposisi mikrobiota usus terdiri dari lebih kurang $10^{13}-10^{14}$ bakteri dan kebanyakan termasuk dalam phylum Firmicutes dan Bacteroidetes. ${ }^{6,7}$ Mikrobiota usus unik untuk setiap individu, berkembang seumur hidup, dan dapat diubah oleh faktor internal dan eksternal (khususnya diet). ${ }^{8}$ Komposisi mikrobiota usus dalam diri individu dipengaruhi oleh faktor internal seperti genotipe dan usia dan serta faktor eksternal seperti pola makan, prebiotik dan antibiotik. ${ }^{9}$ Dinamika komposisi dari mikrobiota usus dipengaruhi oleh diet atau gaya hidup lainnya belum sepenuhnya dipahami. Selain itu, untuk mengategorikan komposisi mikrobiota usus manusia berdasarkan variasi besarnya antara individu sangat sulit. ${ }^{10}$

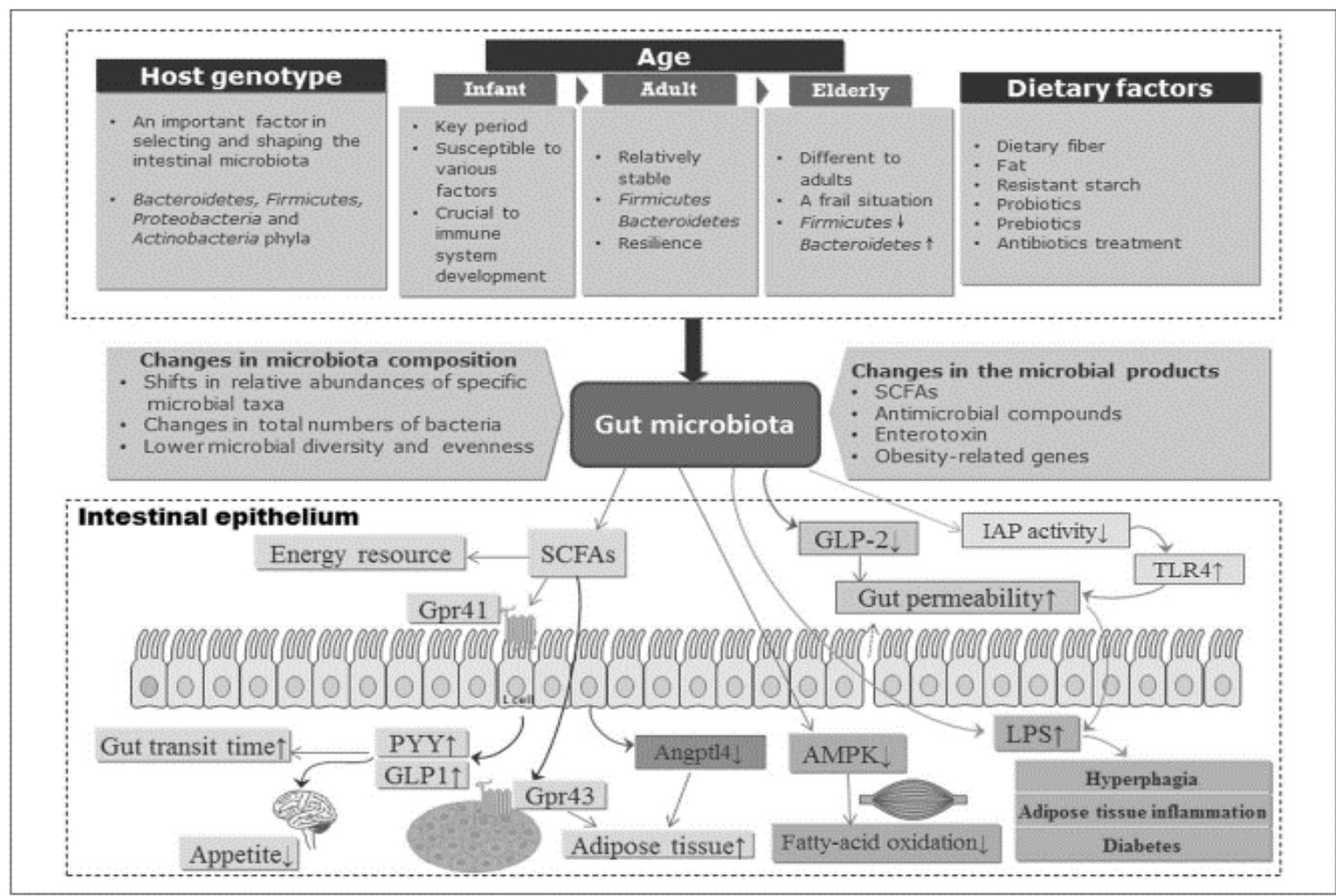

Gambar 1. Komposisi mikroba usus berhubungan dengan genotipe host, usia, dan faktor makanan ${ }^{9}$

Mikrobiota usus dipengaruhi oleh usia, kebiasaan makan dan asal geografis. Peran dari mikrobiota masih belum diketahui dengan jelas, tetapi bakteri flora usus memberikan kontribusi enzim yang ada pada manusia dan memainkan peran penting dalam katabolisme serat makanan. ${ }^{11}$ Komposisi mikrobiota sangat berhubungan dengan pola makan, dimana jumlah Bacteroides berhubungan dengan asupan makanan yang berasal dari hewan (animal product) sedangkan jumlah Prevotella berhubungan dengan asupan makanan yang berasal dari tumbuhan (plant-based foods). ${ }^{12}$ Nakayama et al menemukan Prevotella mendominasi mikrobiota usus mayoritas populasi 
Indonesia dan Khon Kaen di Thailand yang mayoritas penduduknya mengonsumsi nasi. ${ }^{13}$

Komposisi mikrobiota ini juga dapat dipengaruhi oleh sejumlah faktor termasuk usia, diet, dan pengobatan antibiotik ${ }^{7}$ serta dipengaruhi aktivitas fisik. ${ }^{14}$ Peningkatan jenis mikrobiota usus hanya terjadi pada jenis Lactobacillus ruminis, Bifidobacterium adolescentis dan rasio Firmicutes/Bacteroidetes, tetapi tidak ada perbedaan yang bermakna antara kelompok aktivitas ringan dan sedang. Hasil ini berbeda dengan penelitian yang dilakukan pada mencit, dimana mencit yang melakukan aktivitas fisik mempunyai Lactobacillus lebih banyak dibandingkan yang tidak melakukan aktivitas fisik. ${ }^{15}$ Queipo-Ortuño et al (2013) juga melaporkan korelasi positif antara jumlah Bifidobacterium dan Lactobacillus dengan serum leptin dan korelasi negatif jumlah Clostridium, Bacteroides dan Prevotella dengan serum leptin. Sedangkan kadar serum ghrelin mempunyai korelasi negatif dengan jumlah Bifidobacterium, Lactobacillus dan B. coccoidesEubacterium dan korelasi positif dengan jumlah Bacteroides dan Prevotella. ${ }^{16}$ Mekanisme aktivitas fisik menyebabkan perubahan profil mikrobiota sampai sekarang belum diketahui dengan pasti. Beberapa mekanisme yang diyakini adalah pengaruh asam empedu, Short Chain Fatty Acid (SCFA), Lipopolisakarida (LPS), miokines, penurunan berat badan, Hipotalamus-Pituitary-Adrenal Axis (HPA Axis) dan penurunan transit time di usus. ${ }^{14}$

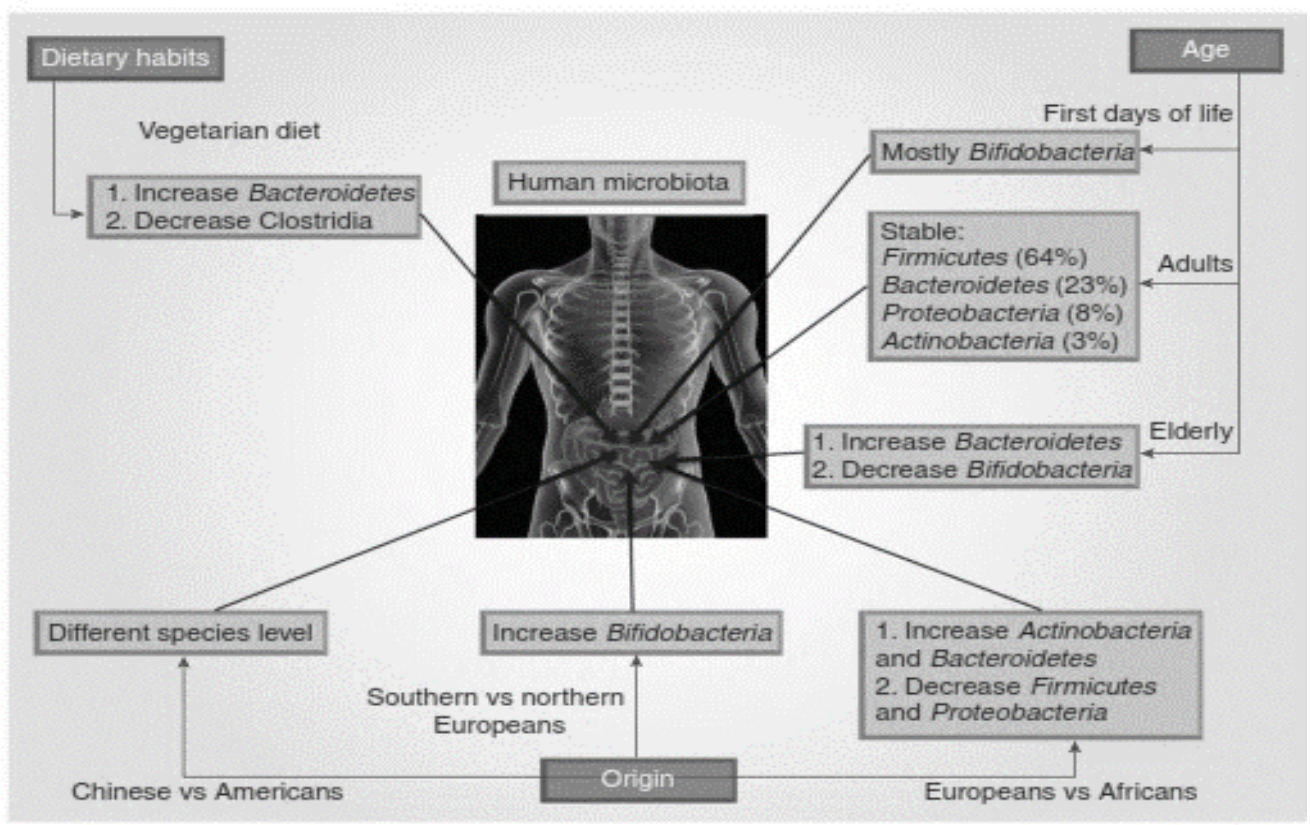

Gambar 2. Efek berbagai faktor terhadap komposisi mikrobiota usus $^{11}$

Sebagian besar mikrobiota usus termasuk ke dalam filum Firmicutes dan Bacteroidetes. Meskipun sangat stabil dari waktu ke waktu, komposisi dan kegiatan mikrobiota ini dapat dipengaruhi oleh sejumlah faktor termasuk usia, diet, dan pengobatan antibiotik. Gangguan 
keseimbangan mikrobiota usus sering dihubungkan dengan proses inflamasi dan gangguan metabolik seperti (inflammatory bowel diseases, irritable bowel syndrome dan obesitas). ${ }^{7}$ Perubahan yang signifikan dalam komposisi dari mikrobiota usus telah ditemukan pada tikus gemuk, menunjukkan bahwa perbedaan dalam flora usus dapat menjelaskan beberapa risiko obesitas. Proporsi bakteri menguntungkan Bacteroidetes lebih rendah pada obesitas dibandingkan individu normal, dan proporsi ini meningkat dengan penurunan berat badan yang disebabkan oleh diet kalori rendah. ${ }^{17}$

Peran mikrobiota usus terhadap perkembangan obesitas

Mekanisme pasti peran mikrobiota usus terhadap perkembangan obesitas masih belum jelas. Walaupun ada beberapa mekanisme utama peran mikrobiota terhadap perkembangan obesitas. Mikrobiota usus merupakan organ metabolik yang dapat memfermentasi karbohidrat yang tidak bisa dicerna (nondigestible carbohydrates) untuk menghasilkan Short Chain Fatty Acids (SCFA), yang mengatur penyimpanan lemak (lipogenesis) melalui Carbohydrate Response Element Binding Protein (ChREBP) dan Sterol Response Element Binding Protein 1 (SREBP1) serta melalui penekanan fasting induced adipocyte factor atau Angiopoitein-Like Protein 4 (Fiaf/ANGPTL4) sebagai penghambat lipoprotein lipase LPL yang mengakibatkan penumpukan lemak di jaringan perifer. ${ }^{18}$ Fiaf diproduksi oleh white dan brown adipose tissue serta usus halus yang menghambat lipoprotein lipase (LPL) yang mengakibatkan penurunan oksidasi asam lemak di jaringan adiposa dan jaringan otot. $^{19}$

Di samping itu mikrobiota juga dapat mempengaruhi homeostasis energi dan energy harvesting. ${ }^{20,21}$ Mikrobiota usus dapat memfermentasi karbohidrat kompleks menjadi monosakarida dan SCFA yang kemudian dapat disimpan sebagai jaringan adiposa atau memberikan nutrien untuk pertumbuhan mikroba. Kekurangan enzim tertentu untuk degradasi karbohidrat yang tidak dapat dicerna (nondigestible carbohydrates), menyebabkan sebagian besar makanan tersebut sampai di usus besar dimana mikrobiota anaerob akan menggunakan sebagai substrat untuk difermentasi. ${ }^{22}$ Proses fermentasi tidak hanya mengubah komposisi dan aktivitas mikrobiota usus saja tapi juga menghasilkan metabolit bioaktif yang dapat mencapai sirkulasi sistemik. Metabolit utama dari diet karbohidrat adalah SCFA yaitu asetat, propionat dan butirat yang merupakan sumber energi baru bagi tubuh, di samping itu SCFA juga menstimulasi proses adipogenesis. ${ }^{23}$ Semakin besar efisiensi ekstraksi energi dari mikrobiota, semakin besar kecenderungan seorang individu dapat berkembang menjadi obesitas. Ekstraksi energi ini juga dipengaruhi oleh faktor lain seperti ketersediaan substrat, lama transit di usus, absorpsi mukosa dan keseimbangan mikrobiota usus. ${ }^{24}$ 
Konsentrasi SCFA pada obesitas $(103,9 \pm 34,3 \mathrm{mmol} / \mathrm{l})$ signifikan lebih tinggi dibandingkan overweight $(98,7 \pm 33,9 \mathrm{mmol} / \mathrm{l})$ dan normal $(84,6 \pm 22,9 \mathrm{mmol} / \mathrm{l}) .{ }^{25}$ Penelitian mendapatkan perubahan asupan makan dapat mempengaruhi komposisi mikrobiota dan meningkatkan energy harvest sekitar $150 \mathrm{kcal} .{ }^{26}$ Selain itu SCFA juga dapat mempengaruhi insulin sensitivity dan metabolisme energi melalui beberapa mekanisme, yang meliputi komponen sistem saraf pusat. SCFA dapat memodifikasi beberapa hormon usus yang terlibat dalam homeostasis glukosa dan energi. Mekanisme molekuler dari fungsi SCFA masih belum diketahui, tetapi studi terkini mendapatkan bahwa $G$ protein couple receptor (GPCRs) berikatan dengan produk mikrobiota (SCFA) yang berkontribusi terhadap pengaturan intake makanan dan pembentukan lemak. Beberapa studi melaporkan SCFA yang berikatan dengan reseptor di enteroendokrin sel akan menyekresikan modulator glukosa homeostasis seperti Peptide YY (PYY), GLP1. 27,28 Glucagon like peptide-1 (GLP-1) memegang peranan penting dalam pengaturan antara asupan makanan dan organ perifer seperti otak, otot dan jaringan adiposa dengan meningkatkan nafsu makan dan waktu transit di usus. ${ }^{29}$ Perubahan komposisi mikrobiota usus dapat memicu kejadian obesitas dan gangguan metabolik melalui perubahan metabolisme asam empedu dan FXR/TGR5 signaling. ${ }^{28}$

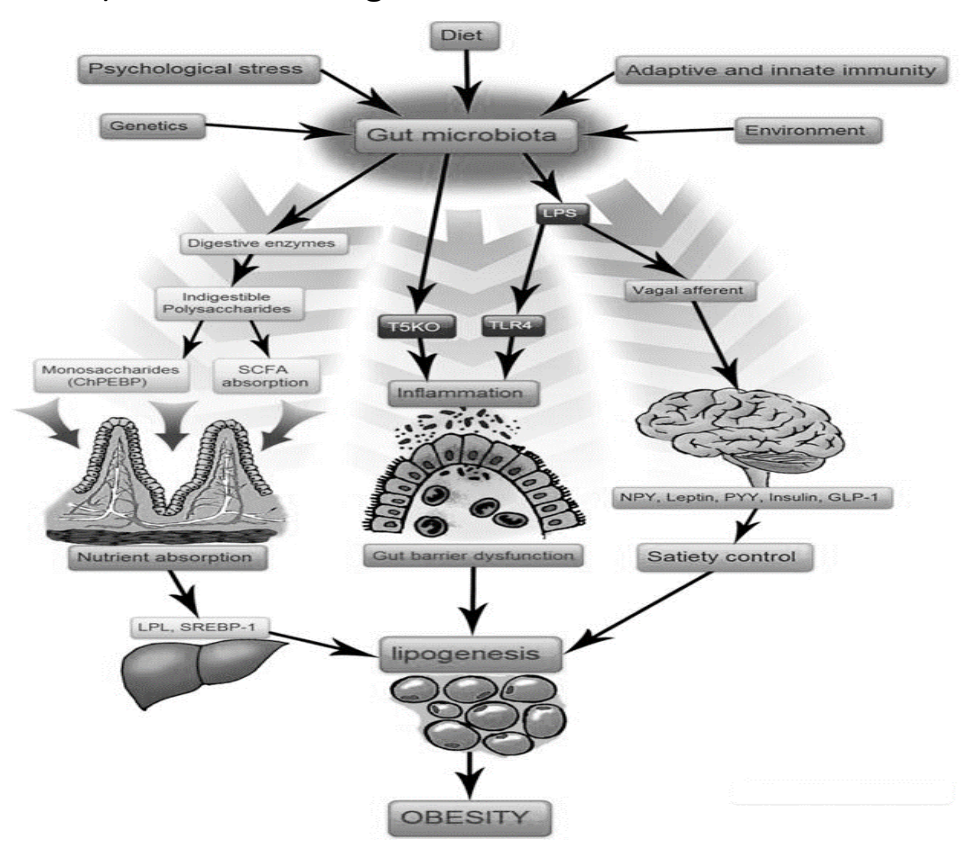

Gambar 3. Mekanisme mikrobiota usus mengendalikan obesitas. Mikrobiota dapat mempengaruhi jalur metabolik dengan memodulasi energi harvesting, inflamasi dan kontrol rasa kenyang ${ }^{30}$

Mikrobiota usus dapat menyebabkan inflamasi kronik (chronic low-grade inflammation) dan obesitas melalui absorpsi Lipopolisakarida (LPS). LPS merupakan komponen struktural penting dari dinding sel bakteri gram negatif, bertindak sebagai faktor trigerring yang 
menghubungkan inflamasi sistemik untuk diet tinggi lemak. ${ }^{31}$ Perubahan komposisi mikrobiota juga mempengaruhi fungsi permeabilitas usus. $^{32}$ Studi lain yang menghubungkan obesitas dengan sistem endocannabinoid yang mengatur metabolisme dan rasa lapar melalui microbiota-gut-brain axis, yang berperan dalam energy homeostasis. Sistem endocannabinoid (eCB) tidak hanya mengontrol permeabilitas usus tetapi juga kadar LPS plasma dan proses adipogenesis. ${ }^{28,33}$

Selain mikrobiota usus mempengaruhi jalur metabolik melalui energy harvesting, juga memberikan sinyal di luar usus ke otak. Beberapa studi menunjukkan bahwa mikrobiota usus bisa mengaktifkan neuron sensorik vagal dan wilayah otak yang berhubungan dengan jaringan otonom pusat. Studi menunjukkan bahwa mikrobiota usus dapat mempengaruhi perkembangan regulasi pusat nafsu makan dan kenyang. ${ }^{30}$ Perubahan mikrobiota dapat mempengaruhi sistem saraf pusat dan perifer yang menghasilkan perubahan fungsi otak (microbiota gut-brain axis). ${ }^{34}$

\section{SIMPULAN}

Komposisi mikrobiota usus dalam diri individu dipengaruhi oleh faktor internal seperti genotipe dan usia dan serta faktor eksternal seperti pola makan, prebiotik dan antibiotik dan aktivitas fisik. Gangguan keseimbangan mikrobiota usus sering dihubungkan dengan proses inflamasi dan gangguan metabolik antara lain obesitas. Beberapa penelitian menunjukkan mekanisme utama peran mikrobiota terhadap perkembangan obesitas dapat melalui jalur metabolik, inflamasi, maupun hormonal. Salah satu cara yang disarankan untuk menurunkan kejadian obesitas adalah memodifikasi komposisi mikrobiota dengan memperhatikan faktor internal dan eksternal terutama diet.

\section{DAFTAR PUSTAKA}

1. Daniels SR, Arnett DK, Eckel RH, Gidding SS, Hayman LL, Kumanyika S, et al. Overweight in children and adolescents: pathophysiology, consequences, prevention, and treatment. Circulation. 2005; 111(15):1999-2012. doi: 10.1161/01.CIR.0000161369.71722.10.

2. Kyrou I, Randeva HS, Tsigos C, Kaltsas G, Weickert MO. Clinical Problems Caused by Obesity. In: Hershman JM, Morley JE, editors. Endocrinology of Aging. South Dartmouth: MDText.com, Inc.; 2018. Available from: https://www.ncbi.nlm.nih.gov/books/NBK278973/.

3. Keating CL, Moodie ML, Swinburn BA. The health-related quality of life of overweight and obese adolescents--a study measuring body mass index and adolescent-reported perceptions. Int J Pediatr Obes. 2011; 6(5-6):434-41. doi: 10.3109/17477166.2011.590197.

4. Garver WS, Newman SB, Gonzales-Pacheco DM, Castillo JJ, Jelinek D, Heidenreich RA, et al. The genetics of childhood obesity and interaction with dietary macronutrients. Genes Nutr. 2013; 8(3):271-287. doi: 10.1007/s12263-013-0339-5. 
5. Clarke SF, Murphy EF, Nilaweera K, Ross PR, Shanahan F, O'Toole PW, et al. The gut microbiota and its relationship to diet and obesity: new insights. Gut Microbes. 2012; 3(3):186-202. doi: 10.4161/gmic.20168.

6. Tsai F, Coyle WJ. The microbiome and obesity: is obesity linked to our gut flora? Curr Gastroenterol Rep. 2009; 11(4):307-13.

7. Power SE, O'Toole PW, Stanton C, Ross RP, Fitzgerald GF. Intestinal microbiota, diet and health. Br J Nutr. 2014; 111(3):387-402. doi: 10.1017/S0007114513002560.

8. Kang JX. Gut microbiota and personalized nutrition. J Nutrigenet Nutrigenomics. 2013; 6(2):I-II. Doi: $10.1159 / 000353144$.

9. Chen J, He X, Huang J. Diet effects in gut microbiome and obesity. J Food Sci. 2014; 79(4):R442451. doi: 10.1111/1750-3841.12397.

10. Kussmann M, van Bladeren PJ. The Extended Nutrigenomics - Understanding the Interplay between the Genomes of Food, Gut Microbes, and Human Host. Front Genet. 2011; 2:21. Doi: 10.3389/fgene.2011.00021.

11. Angelakis $E$, Armougom F, Million M, Raoult D. The relationship between gut microbiota and weight gain in humans. Future Microbiol. 2012; 7(1):91-109. doi: 10.2217/fmb.11.142.

12. Wu Gd, Chen J , Hoffman C. Linking Long-Term Dietary Patterns with Gut Microbial Enterotypes. Science. 2011; 334(6052):105-108. doi: 10.1126/science.1208344.

13. Nakayama J, Watanabe K, Jiang J, Matsuda K, Chao SH, Haryono P, et al. Diversity in gut bacterial community of school-age children in Asia. Scientific Report. 2015; 5:8397. doi: 10.1038/srep08397.

14. Cerda B, Perez M, Santiago JP. Gut Microbiota Modification: Another Piece in the Puzzle of the Benefits of Physical Exercise in Health?. Front Physiol, 2016. 7: 51. Published online 2016 Feb 18. doi: 10.3389/fphys.2016.00051

15. Choi JJ, Eum SY, Rampersaud E, Daunert S, Abreu MT, Toborek M. Exercise Attenuates PCBInduced Changes in the Mouse Gut Microbiome. Environ Health Perspect. 2013; 121(6):725-730. doi: 10.1289/ehp.1306534.

16. Queipo-Ortuño MI, Seoane LM, Murri M, Pardo M, Gomez-Zumaquero JM, Cardona F, et al. Gut Microbiota Composition in Male Rat Models under Different Nutritional Status and Physical Activity and Its Association with Serum Leptin and Ghrelin Levels. Plos One; 2013; 8(5):e65465. doi: 10.1371/journal.pone.0065465.

17. Rawls JF, Mahowald MA, Ley RE, Gordon JI. Reciprocal gut microbiota transplants from zebrafish and mice to germ-free recipients reveal host habitat selection. Cell. 2006; 127(2):423-433. doi: 10.1016/j.cell.2006.08.043.

18. Backhed F, Ding H, Wang T, Hooper LV, Koh GY, Nagy A, et al. The gut microbiota as an environmental factor that regulates fat storage. Proc Natl Acad Sci U S A . 2004; 101(44):15718 15723. doi: 10.1073/pnas.0407076101.

19. Conterno L., Fava F., Viola R., Tuohy K.M. Obesity and the gut microbiota: Does up-regulating colonic fermentation protect against obesity and metabolic disease?. Genes Nutr. 2011; 6:241260. doi: $10.1007 / \mathrm{s} 12263-011-0230-1$. 
20. Parekh PJ, Arusi E, Vinik Al, Johnson DA. The role and influence of gut microbiota in pathogenesis and management of obesity and metabolic syndrome. Front Endocrinol (Lausanne). 2014; 5:47. doi: $10.3389 /$ fendo.2014.00047.

21. Turnbaugh PJ, Ley RE, Mahowald MA, Magrini V, Mardis ER, Gordon JI. An obesity-associated gut microbiome with increased capacity for energy harvest. Nature. 2006; 444(7122):1027-1031. doi: $10.1038 /$ nature05414.

22. den Besten G, van Eunen K, Groen AK, Venema K, Reijngoud DJ, Bakker BM. The role of shortchain fatty acids in the interplay between diet, gut microbiota, and host energy metabolism. J. Lipid Res. 2013; 54(9):2325-2340. doi: 10.1194/ilr.R036012.

23. Duncan SH1, Belenguer A, Holtrop G, Johnstone AM, Flint HJ, Lobley GE. Reduced dietary intake of carbohydrates by obese subjects results in decreased concentrations of butyrate and butyrate-producing bacteria in feces. Appl Environ Microbiol. 2007; 73(4):1073-1078. doi: 10.1128/AEM.02340-06.

24. Shen J, Obin MS, Zhao L. 2013. The gut microbiota, obesity and insulin resistance. Mol Aspects Med. 2013; 34(1):39-58. doi: 10.1016/j.mam.2012.11.001.

25. Schwiertz A, Taras D, Schäfer K, Beijer S, Bos NA, Donus C, et al. Microbiota and SCFA in Lean and Overweight Healthy Subjects. Obesity (Silver Spring). 2010; 18(1):190-195. doi: 10.1038/oby.2009.167.

26. Jumpertz R1, Le DS, Turnbaugh PJ, Trinidad C, Bogardus C, Gordon JI, et al. Energy-balance studies reveal associations between gut microbes, caloric load, and nutrient absorption in humans. Am J Clin Nutr. 2011; 94(1):58-65. doi: 10.3945/ajcn.110.010132.

27. Chambers ES, Viardot A, Psichas A, Morrison DJ, Murphy KG, Zac-Varghese SE, et al. Effects of targeted delivery of propionate to the human colon on appetite regulation, body weight maintenance and adiposity in overweight adults. Gut. 2015; 64(11):1744-54. doi: 10.1136/gutjnl2014-307913.

28. Aguirre M, Venema K. Does the Gut Microbiota Contribute to Obesity? Going beyond the Gut Feeling. Microorganisms. 2015; 3(2):213-235. doi: 10.3390/microorganisms3020213.

29. Holst JJ. The physiology of glucagon-like peptide 1. Physiological Reviews. 2007; 87(4):14091439. doi: 10.1152 /physrev.00034.2006.

30. Tehrani AB, Nezami BG, Gewirtz A, Srinivasan S. Obesity and its associated disease: a role for microbiota?. Neurogastroenterol Motil. 2012; 24(4):305-311. doi: 10.1111/i.13652982.2012.01895.x.

31. Kobyliak N, Virchenko A, Falalyeyeva T. Pathophysiological role of host microbiota in the development of obesity. Nutrition J. 2016; 15:43. doi: 10.1186/s12937-016-0166-9.

32. Cani PD, Possemiers $S$, Van de Wiele $T$, Guiot $Y$, Everard A, Rottier $O$, et al. Changes in gut microbiota control inflammation in obese mice through a mechanism involving GLP-2-driven improvement of gut permeability. Gut. 2009; 58(8):1091-1103. doi: 10.1136/gut.2008.165886.

33. Muccioli GG1, Naslain D, Bäckhed F, Reigstad CS, Lambert DM, Delzenne NM, et al. The endocannabinoid system links gut microbiota to adipogenesis. Mol Syst Biol. 2010; 6:392. doi: $10.1038 / \mathrm{msb} .2010 .46$.

34. Bienenstock J, Kunze W, Forsythe P. Microbiota and the gut-brain axis. Nutr Rev. 2015; 73(Suppl.1):28-31. doi: 10.1093/nutrit/nuv019. 